\title{
Effective Communication as a Panacea for Gaining Acceptance of Hospital Services by Clients
}

\author{
Article by Onwubiko Iheanyichukwu Samuel \\ Master of Public Health, Texila American University, Nigeria \\ E-mail: sammyblackjeese@yahoo.com
}

\begin{abstract}
Health communication is essential in providing avenue for effective dissemination of health information in order to improve healthcare delivery. Lack of effective communication between healthcare providers and their clients especially in secondary health facilities has impeded the effective and efficient delivery of quality healthcare. The objective of this study is to demonstrate effective communication as a solution for clients to accept quality healthcare services.

A descriptive cross-sectional study of three secondary health facilities in Northern Cross River, Nigeria. Population of 2050 in 3 facilities with sample size (n) of 335 allocated 147, 57, 98 and 33 among the 3 facilities and staff categories respectively. Systematic sampling technique was used and semi-structured self-administered questionnaire for data collection. Data analysis was done using statistical package for social science. Non-parametric statistics was used in the analysis as data was categorical and not normally distributed.

Out of 335 respondents, 278 completed the questionnaire giving a response rate of $83 \%$. Modal Age group is 25-34 (29.5\%) and Modal level of education is tertiary (38.5\%). Majority of clients (53.6\%) concurred to good communication skills (listening skills and allowing feedback from patient) from healthcare providers improved acceptance to healthcare delivery $(P=0.019)$. Majority (45.3\%) who confirmed friendly approach of health workers maintained them as their health providers.

Effective communication is key to acceptance of services rendered to clients by healthcare personnel and also, for clients to have a positive perception of services rendered.
\end{abstract}

Keywords: Communication barriers, communication tools, acceptance, healthcare delivery, healthcare provider, cross river,

\section{Introduction}

The lack of effective communication between healthcare personnel and their clients in the hospital setting impedes the effective and efficient delivery of quality clinical and healthcare services and this negatively affects the successful partnership in the hospital setting, resulting in industrial disputes among staff as well as adverse effects on patients. Health communication thus, is essential as it provides an avenue for effective dissemination of health information in order to improve healthcare delivery. Also, since communication is essential in ensuring adequate provider-client relationship, it is imperative that a strong positive relationship is established between a healthcare team member's communication skills and a patient's capacity to follow through with medical recommendations, self-manage a chronic medical condition, and adopt preventive health behaviors. This study was conducted in the three (3) high volume secondary health facilities (General hospital Ogoja, Catholic Monaya Hospital Ogoja and Sacred heart Catholic Hospital) in the Northern District of Cross River state. The specific objectives of this study include:

- To examine the perception of clients on the quality and suitability of verbal and nonverbal communication strategies employed by healthcare personnel in secondary health facilities.

- To assess the feedback and responses of clients to relevant clerking sessions by healthcare workers in secondary health facilities. 
Texila International Journal of Public Health

Volume 4, Issue 4, Dec 2016

- To identify the various communication barriers and evaluate strategies aimed at preventing and overcoming the barriers to effective communication in the hospital.

- To describe the usefulness of communication tools such as listening skills, media, reference materials used by healthcare personnel in ensuring effective client acceptance and patient management.

\section{Methods}

The study was conducted in three (3) high volume secondary health facilities in Northern District of Cross River State in Nigeria. They are General Hospital Ogoja (GH Ogoja), Catholic Monaya Hospital Ogoja (CMH Ogoja) and Sacred Heart Catholic Hospital Obudu (SHCH Obudu).

The study type is descriptive cross-sectional study in which a thorough description of the concept of effective communication is analyzed as well as the type of responses from respondents. The population that was used for the study encompassed all the clients that access healthcare at GH Ogoja, CMH Ogoja and SHCH, Obudu. The average client attendance at General Hospital Ogoja is 900 clients, while CMH Monaiya has about 600 clients and SHCH Obudu has about 350 clients. The facilities also have combined staff strength of about 200 staff. Hence, giving a total population of 2050 was used. The Sample size used for the study was determined using the Taro Yamane’s formula thus;

$\mathrm{n}=$

$$
\frac{\mathrm{N}}{1+\mathrm{N}(\mathrm{e})^{2}}
$$

Where;

$\mathrm{n}=$ Sample size.

$\mathrm{N}=$ Total population size.

$\mathrm{e}=$ level of significance.

The Bourley's1964 population allocation formula was used to determine the sample size per health care facility. The formula is stated as follows;

$$
\mathrm{nh}=\frac{\mathrm{n} \mathrm{x} \mathrm{Nh}}{\mathrm{N}}
$$

Where;

nh=Sample size per health facility.

$\mathrm{Nh}=$ Total number of clients in each health facility.

$\mathrm{N}=$ Total Population size.

$\mathrm{n}=$ Total sample size.

Thus, 147 client responses were considered at GH Ogoja, while 98 and 57 were considered at $\mathrm{CMH}$ Monaiya and SHCH Obudu respectively. Also, 33 responses will be obtained from staff of the facility

The Sampling procedure utilized was the systematic sampling technique, a probability sampling procedure.

In this procedure, a respondent was chosen such that the first person is picked at random from the start. After this, every second name was then selected as computed by the formula below;

For GH Ogoja,

$$
\mathrm{K}=\frac{\mathrm{N}^{-}=}{\mathrm{n}} \frac{900=6.1}{147}=6
$$

For CMH Monaiya,

$$
\mathrm{K}=\frac{\mathrm{N}}{\mathrm{n}}=\underset{98}{600}=6.1=6
$$

For SHCH Obudu, 
For Staff across the facilities,

$$
\mathrm{K}=\frac{\mathrm{N}}{\mathrm{n}}=\frac{350=6.1}{57}=6
$$

$$
\mathrm{K}=\frac{\mathrm{N}}{\mathrm{n}}=\frac{200=6.1}{33}=6
$$

Hence, every $6^{\text {th }}$ client was selected until the sample size of 147, 98, 57 and 33 was obtained at GH Ogoja, CMH Monaiya, SHCH Obuduand staff across the facilities respectively.

The data collection technique utilized for the survey include the use of data collecting instruments such as a semi-structured self-administered questionnaire to collect primary data. The data was analyzed using Statistical Package for Social Science tool. Also, since the research entails an evaluation of the perception of clients on the efficacy of communication with healthcare providers, it is observed that two groups are involved, i.e. the client and the provider, hence, we utilized the principles of Inferential Statistics for the study.

Consequently, non-parametric statistics method is used to analyze data, it assumes that data is categorical and in some cases, it may be continuous but not normally distributed.

\section{Results}

The responses obtained after administration of questionnaires were tabulated and frequency tables and charts generated

Table 1: Age in years

\begin{tabular}{|l|l|c|c|c|c|}
\hline & & Frequency & Percent & $\begin{array}{c}\text { Valid } \\
\text { Percent }\end{array}$ & $\begin{array}{c}\text { Cumulative } \\
\text { Percent }\end{array}$ \\
\hline Valid & $15-24$ & 54 & 19.4 & 19.4 & 19.4 \\
& $25-34$ & 82 & 29.5 & 29.5 & 48.9 \\
$35-44$ & 64 & 23.0 & 23.0 & 71.9 \\
$45-54$ & 37 & 13.3 & 13.3 & 85.3 \\
$55-64$ & 25 & 9.0 & 9.0 & 94.2 \\
$65-74$ & 9 & 3.2 & 3.2 & 97.5 \\
& $>75$ & 7 & 2.5 & 2.5 & 100.0 \\
\cline { 2 - 6 } & Total & 278 & 100.0 & 100.0 & \\
\hline
\end{tabular}

Table 2: Level of Education

\begin{tabular}{|l|l|c|c|c|c|}
\hline & & Frequency & Percent & $\begin{array}{c}\text { Valid } \\
\text { Percent }\end{array}$ & $\begin{array}{c}\text { Cumulative } \\
\text { Percent }\end{array}$ \\
\hline Valid & No formal & 56 & 20.1 & 20.1 & 20.1 \\
& Education & & & & \\
& Primary & 41 & 14.7 & 14.7 & 34.9 \\
& Secondary & 74 & 26.6 & 26.6 & 61.5 \\
& Tertiary & 107 & 38.5 & 38.5 & 100.0 \\
& Total & 278 & 100.0 & 100.0 & \\
\hline
\end{tabular}


Texila International Journal of Public Health

Volume 4, Issue 4, Dec 2016

Table 3: Preference of care

\begin{tabular}{|l|l|c|c|c|c|}
\hline & & Frequency & Percent & $\begin{array}{c}\text { Valid } \\
\text { Percent }\end{array}$ & $\begin{array}{c}\text { Cumulative } \\
\text { Percent }\end{array}$ \\
\hline Valid & Strongly & 148 & 53.2 & 53.2 & 53.2 \\
& Agree & 73 & 26.3 & 26.3 & 79.5 \\
& Agree & 8 & 2.9 & 2.9 & 82.4 \\
& Not sure & 5 & 1.8 & 1.8 & 84.2 \\
& Disagree & 44 & 15.8 & 15.8 & 100.0 \\
& Strongly & & & & \\
& disagree & 278 & 100.0 & 100.0 & \\
& Total & & & & \\
\hline
\end{tabular}

Table 4: Non verbal techniques utilized

\begin{tabular}{|l|l|c|c|c|c|}
\hline & & Frequency & Percent & $\begin{array}{c}\text { Valid } \\
\text { Percent }\end{array}$ & $\begin{array}{c}\text { Cumulative } \\
\text { Percent }\end{array}$ \\
\hline Valid & Strongly agree & 149 & 53.6 & 53.6 & 53.6 \\
& Agree & 76 & 27.3 & 27.3 & 80.9 \\
& Not sure & 5 & 1.8 & 1.8 & 82.7 \\
Disagree & 8 & 2.9 & 2.9 & 85.6 \\
& Strongly & 40 & 14.4 & 14.4 & 100.0 \\
& disagree & & & & \\
& Total & 278 & 100.0 & 100.0 & \\
\hline
\end{tabular}

Table 5: Careful listening

\begin{tabular}{|l|l|c|c|c|c|}
\hline & & Frequency & Percent & $\begin{array}{c}\text { Valid } \\
\text { Percent }\end{array}$ & $\begin{array}{c}\text { Cumulative } \\
\text { Percent }\end{array}$ \\
\hline Valid & Strongly agree & 116 & 41.7 & 41.7 & 41.7 \\
& Agree & 102 & 36.7 & 36.7 & 78.4 \\
& Not sure & 8 & 2.9 & 2.9 & 81.3 \\
& Disagree & 10 & 3.6 & 3.6 & 84.9 \\
& Strongly & 42 & 15.1 & 15.1 & 100.0 \\
& Disagree & & & & \\
Total & 278 & 100.0 & 100.0 & \\
\hline
\end{tabular}

Table 6: Friendliness of staff

\begin{tabular}{|l|l|c|c|c|c|}
\hline & & Frequency & Percent & $\begin{array}{c}\text { Valid } \\
\text { Percent }\end{array}$ & $\begin{array}{c}\text { Cumulative } \\
\text { Percent }\end{array}$ \\
\hline Valid & Strongly Agree & 126 & 45.3 & 45.3 & 45.3 \\
& Agree & 102 & 36.7 & 36.7 & 82.0 \\
& Not sure & 26 & 9.4 & 9.4 & 91.4 \\
& Disagree & 15 & 5.4 & 5.4 & 96.8 \\
& Strongly & 9 & 3.2 & 3.2 & 100.0 \\
& Disagree & & & & \\
& Total & 278 & 100.0 & 100.0 & \\
\hline
\end{tabular}


Table 7: Clarity of Communication

\begin{tabular}{|l|l|c|c|c|c|}
\hline & & Frequency & Percent & $\begin{array}{c}\text { Valid } \\
\text { Percent }\end{array}$ & $\begin{array}{c}\text { Cumulative } \\
\text { Percent }\end{array}$ \\
\hline Valid & Strongly Agree & 121 & 43.5 & 43.5 & 43.5 \\
& Agree & 113 & 40.6 & 40.6 & 84.2 \\
& Not sure & 19 & 6.8 & 6.8 & 91.0 \\
& Disagree & 15 & 5.4 & 5.4 & 96.4 \\
& Strongly & 10 & 3.6 & 3.6 & 100.0 \\
& Disagree & & & & \\
Total & 278 & 100.0 & 100.0 & \\
\hline
\end{tabular}

Table 8: Verbal communication

\begin{tabular}{|l|l|c|c|c|c|}
\hline & & Frequency & Percent & $\begin{array}{c}\text { Valid } \\
\text { Percent }\end{array}$ & $\begin{array}{c}\text { Cumulative } \\
\text { Percent }\end{array}$ \\
\hline Valid & Strongly Agree & 108 & 38.8 & 38.8 & 38.8 \\
& Agree & 111 & 39.9 & 39.9 & 78.8 \\
& Not sure & 24 & 8.6 & 8.6 & 87.4 \\
Disagree & 20 & 7.2 & 7.2 & 94.6 \\
Strongly & 15 & 5.4 & 5.4 & 100.0 \\
Disagree & & & & \\
Total & 278 & 100.0 & 100.0 & \\
\hline
\end{tabular}

Table 9: Change in communication

\begin{tabular}{|l|l|c|c|c|c|}
\hline & & Frequency & Percent & $\begin{array}{c}\text { Valid } \\
\text { Percent }\end{array}$ & $\begin{array}{c}\text { Cumulative } \\
\text { Percent }\end{array}$ \\
\hline Valid & Strongly agree & 66 & 23.7 & 23.7 & 23.7 \\
& Agree & 76 & 27.3 & 27.3 & 51.1 \\
& Not sure & 44 & 15.8 & 15.8 & 66.9 \\
& Disagree & 30 & 10.8 & 10.8 & 77.7 \\
& Strongly & 62 & 22.3 & 22.3 & 100.0 \\
& disagree & & & & \\
& Total & 278 & 100.0 & 100.0 & \\
\hline
\end{tabular}

Table 10: Quality of Communication

\begin{tabular}{|l|l|c|c|c|c|}
\hline & & Frequency & Percent & $\begin{array}{c}\text { Valid } \\
\text { Percent }\end{array}$ & $\begin{array}{c}\text { Cumulative } \\
\text { Percent }\end{array}$ \\
\hline Valid & Strongly agree & 136 & 48.9 & 48.9 & 48.9 \\
& Agree & 91 & 32.7 & 32.7 & 81.7 \\
& Not sure & 15 & 5.4 & 5.4 & 87.1 \\
& Disagree & 23 & 8.3 & 8.3 & 95.3 \\
& Strongly & 13 & 4.7 & 4.7 & 100.0 \\
& disagree & & & & \\
& Total & 278 & 100.0 & 100.0 & \\
\hline
\end{tabular}


Texila International Journal of Public Health

Volume 4, Issue 4, Dec 2016

Table 11: Change in Health Provider

\begin{tabular}{|l|l|c|c|c|c|}
\hline & & Frequency & Percent & $\begin{array}{c}\text { Valid } \\
\text { Percent }\end{array}$ & $\begin{array}{c}\text { Cumulative } \\
\text { Percent }\end{array}$ \\
\hline Valid & Strongly agree & 70 & 25.2 & 25.2 & 25.2 \\
& Agree & 77 & 27.7 & 27.7 & 52.9 \\
& Not sure & 40 & 14.4 & 14.4 & 67.3 \\
& Disagree & 41 & 14.7 & 14.7 & 82.0 \\
& Strongly & 50 & 18.0 & 18.0 & 100.0 \\
& disagree & & & & \\
& Total & 278 & 100.0 & 100.0 & \\
\hline
\end{tabular}

Table 12: Suitability of communication strategies employed by healthcare personnel to perception by clients

\begin{tabular}{|l|c|c|c|c|c|}
\hline & $\begin{array}{c}\text { Sum of } \\
\text { Squares }\end{array}$ & Df & $\begin{array}{c}\text { Mean } \\
\text { Square }\end{array}$ & F & Sig. \\
\hline Between & 11.655 & 4 & 2.914 & 1.170 & 0.324 \\
$\begin{array}{l}\text { Groups } \\
\text { Within Groups }\end{array}$ & 679.741 & 273 & 2.490 & & \\
Total & 691.396 & 277 & & & \\
\hline
\end{tabular}

Table 13: Feedback/response of clients to client satisfaction

\begin{tabular}{|l|c|c|c|c|c|}
\hline & $\begin{array}{c}\text { Sum of } \\
\text { Squares }\end{array}$ & Df & $\begin{array}{c}\text { Mean } \\
\text { Square }\end{array}$ & F & Sig. \\
\hline Between & 21.541 & 4 & 5.385 & 3.001 & .019 \\
$\begin{array}{l}\text { Groups } \\
\text { Within Groups }\end{array}$ & 488.091 & 272 & 1.794 & & \\
Total & 509.632 & 276 & & & \\
\hline
\end{tabular}

\section{Discussion}

From the study, it was observed that 335 questionnaires were administered and 278 of the administered copies recovered, representing $83 \%$ retrieval rate. It was also observed that the age group with the most respondents belonged to the $25-34$ range with $29.5 \%$, while the least responses was gotten from participants above 70 years old (Table 1). The level of education of the respondents are majorly tertiary level $38.5 \%$ (Table 2). $53.2 \%$ of the clients strongly agree that they prefer accessing care in the hospitals (Table 3). It was also observed that respondents agreed to the fact that appropriate utilization of the right verbal and non-verbal communication techniques is key to ensuring effective communication in the facilities, subsequently, improving the quality of services. This was reflected in the responses as $39.9 \%$ of respondents said healthcare personnel utilize verbal means of communication (Table 8), while 53.6\% said non-verbal communication is utilized (Table 4). However, the respondents had different individual perceptions on the services offered, depending on the nature of services they received. Some suggested that the health personnel change their manner of communication and about $25.2 \%$ of respondents stated they would like to change their health care provider (Table 11). Also, a computation of the probability values comparing the various views of respondents on the quality of services indicates a value of 0.324 which is greater than (>) 0.05 (Table 12), indicating that there is no significant difference between the perception of clients and the quality of communication strategies offered by healthcare providers. This proves and subsequently accepts the null hypothesis. Furthermore, analysis of the responses indicate that negative attitude of some healthcare staff towards clients has also led to some deciding to change their providers, some even observed that some healthcare providers they had met in some facilities used negative language during communication, this 
has contributed to the different opinions of clients and has further aided the resolve of some to change healthcare providers (Table 11).

From the results of the study, it was observed that $45.3 \%$ of respondents strongly agreed that the healthcare personnel that attended to them were friendly; this generated a feeling of security in them and probably led to their willingness to open up with respect to providing feedback during care and counseling sessions (Table 13). 41.7\% of the clients also indicated that staff often listen to their complaints with considerable attention (Table 5). It was observed that the reactions of clients to healthcare providers during care sessions are greatly dependent on the degree to which they are satisfied with the quality of communication (Table 10). However, it was seen that although majority of clients strongly agreed to the fact that their feedback determined their rate of satisfaction, this result confers a level of significance as reflected in the $\mathrm{p}$ value of 0.019 , which is $<0.05$ (Table 13).

\section{Conclusion}

From the study, it was observed that effective communication is key to the acceptance of services rendered to clients by healthcare personnel. It is also seen that in order for clients to have a positive perception of services rendered, it is important for the providers to make a general improvement in services rendered. It is also observed that the quality of feedback or responses that clients provide to care providers is largely dependent upon the rate of satisfaction as perceived by the clients. This is seen in the responses of clients who believe that with the right attitude by facility staff in the right environment, clients will be encouraged to provide better feedback. Also, it is observed that there is need for healthcare personnel to occasionally change or improve on the quality of their services such as positive behavioral and attitudinal change, improvement of environment of care, greater assurance and education of clients, reduction in patient waiting time, ensuring audio-visual privacy and a change in methods to suite particular clients.

However, it was observed that there exist some barriers to communication in healthcare facilities which are common to the locality where the study was undertaken. They include

Personality, environmental and system level barriers.

Thus, it is concluded that the key to efficient and effective services in the healthcare facilities is effective communication.

\section{Recommendations}

Some of the recommendations generated from the study include;

- The need for an improvement in the environment of communication, which include structural and functional infrastructure.

- The need for creation of audio-visual privacy when attending to clients.

- There is need to ensure effective turnaround time and reduce patient waiting time.

- There is need to carefully and patiently listen to client's concerns before acting.

- It is essential that patients are given sufficient time and opportunity to provide appropriate feedback and response to ensure objective judgment treatment.

- There is need for continuous on the job training and orientation for healthcare personnel on ethics and client management.

- There is need for healthcare providers to occasionally change their methods of communication to specific clients.

- It is essential that diverse communication strategies be put in place to overcome communication barriers.

- There is need for active service units to be put in place in different facilities to obtain regular feedback on the quality of service delivery in the health facilities.

- There is need to engage only experienced and highly qualified healthcare professionals in the healthcare facilities.

- Consider the utilization of interpreters to overcome language barrier. 
Texila International Journal of Public Health

Volume 4, Issue 4, Dec 2016

- The need for healthcare personnel to apply a proper mix of verbal and non-verbal communication techniques to ensure effective communication.

\section{References}

[1.] Aleshire, B. (2010) Effective communication and leadership at health care Site. Retrieved fromhttp://www.slideshare.net/ksllnc/advancing-effective-communication-cultural-competence-andpatient-and-family-centered-care-a-roadmap.

[2.] Baxamusa, B. N. (2010). Communication barriers in healthcare. Retrieved from http://www.buzzle.com/articles/communication-barriers-in-healthcare.html

[3.] Bertalanffy, L.V. (1968). General System theory.

Retrieved from http://www.panarchy.org/vonbertalanffy/systems.1968

[4.] Brown, B. (2014). What is effective communication? Retrieved from http://www.livestrong.com/article/69309-effective-communication/?

[5.] Bryant, D. (2011). Effective Communication and Leadership at Health Care

Sites. Available fromhttp://healthcarecomm.org/about-us/impact-of-communication-in-healthcare/ institute for healthcare communication.

[6.] Clark, P. A. (2003). Medical practices' sensitivity to patients' needs: Opportunities and practices for improvement. Journal of Ambulatory Care Management, 26(2), 110-12.

[7.] Committee on Bioethics, American Academy of Pediatrics. (2008). Informed consent, parental permission, and assent in pediatric practice. Pediatr Rev; 29: e2-e3

[8.] Communication theories, Retrieved from https://en.wikipedia.org/wiki/Communication_theory

[9.] Donald L. R. (1993). "Listen ability = Oral-based Discourse + Considerateness," in Perspectives on Listening, eds. Andrew D. Wolvin and Carolyn Gwynn Coakley (Norwood, NJ: Alex Publishing Corporation), 269.

[10.] Egan (1986) SOLER, Using non-verbal skills to aid Listening. Retrieved from http://retaileap.co.uk

[11.] Foulger, D. (2004). Models of the Communication Process. Available from

http://www.jackwhitehead.com/teesonphd/004c3.pdf

[12.] Hamilton, S.J., Martin, D.J. (2007) A framework for effective communication skills. Extended version of Nursing Times; 103: 48, 30-31

[13.] Handzo, G. (2012). Good communication in health care is about Listening. Retrieved from http://communicationtheory.org/effective-communication/

[14.] Hanes, T. (2013). What is verbal communication? Retrieved from

http://www.livestrong.com/article/150573-what-is-verbal-communication/

[15.] Hanlon, T. (2010). Barriers to effective communication in a hospital

Available from http://www.ehow.com/list_6940461_barriers-effective-communication-hospital.html.

[16.] Harper, D. (2013) "communication". Online Etymology Dictionary.

Retrieved from http://dictionary.reference.com.

[17.] Jain, R. (2008).The Barriers to Effective Communication. Available

From http://www.skillsyouneed.com/ips/barriers-communication.html

[18.] Klapper, J. (1960). The effects of mass communication.

Retrieved from https://books.google.com.ng

[19.] Lasswell, H. (1948). "The structure and function of communication in society." In Lyman Bryson (ed.), The Communication of Ideas. Harper and Row

[20.] Levinson, W., Roter, D., \& Mullooly, J., Dull, V., \& Frankel, R. (1997). Physician-patient communication. The relationship with malpractice claims among primary care physicians and surgeons. JAMA ; 277: 553-9.

[21.] Makaryus, A. N., \& Friedman, E. A. (2005). Patients' understanding of their treatment plans and diagnosis at discharge. Mayo Clinic Proceedings, 80(8), 991-994. pubmed

[22.] Monroe, A. H. (1943). Monroe's principles of speech (military edition). Chicago: Scott, Foresman PN4121.M578. Retrieved from; https://en.wikipedia.org/wiki/Monroe's_motivated_sequence

[23.] National Communication Association (2013) What is communication Retrieved from https://en.wikipedia.org 
[24.] Nelson, L. (2010). Importance of effective communication in healthcare Available from http://www.ehow.com/about_6464377_importance-effective-communication-healthcare.html [25.] Owen H. (2011) Skilled Interpersonal Interaction: Research, Theory, and Practice (London: Routledge), 189-99

[26.] Papa, J. (2009). Effective healthcare communication. Available From http://www.ehow.com/about_5421324_effective-healthcare-communication.html.

[27.] Piette, J. D., Heisler, M., \& Wagner, T. H. (2004). Cost-related medication underuse among chronically ill adults: The treatments people forgo, how often, and who is at risk. American Journal of Public Health, 94(10), 1782-1787.

[28.] Robbins, S., Judge, T., Millett, B., \& Boyle, M. (2011). Organisational behaviour. 6th ed. Pearson, French's Forest, NSW p315-317.

[29.] Robinson, L., Segal, J., Segal, R. (2014). Improving communication skills in business and relationships. Retrieved from http://helpguide.org/mental/effective_communication_skills.htm [30.] Shannon, E. C., \& Weaver, W. (1949). The Mathematical Theory of Communication. Univ of Illinois Press ISBN 0-252-72548-4

[31.] Schattner, A. (2009). The silent dimension: expressing humanism in each medical encounter. Arch Intern Med; 169:1095-99.

[32.] Schwartz, F., Lowe, M., \& Sinclair, L. (2010). Communication in Health Care: Considerations and strategies for successful consumer and team dialogue Hypothesis, 8(1): e7.

[33.] Suresh, K. (2003). Journalism and mass communication. Retrieved from http://en.wikipedia.org/wiki/Communication. P.1-4.

[34.] Thiedke, C. C. (2007). What do we really know about patient satisfaction? Family Practice Management, 33-36. pubmed. Retrieved from http://healthcarecomm.org/about-us/impact-of-communication-in-healthcare/

[35.] Tongue, J., Epps, H., \& Forese, L. (2005). Communication skills for patient- centered care; research-based, easily learned techniques for medical interviews that benefit orthopaedic surgeons and their patients. J Bone Joint Surg Am ; 87:652-8 